\title{
Central incisors shape and proportions prevalence in Argentinian university students: by visual assessment and a new standardized method
}

\author{
María M. Trigo-Humaran', Alan B. Agüero-Romero', Marcela Lespade', Juan M. \\ García-Cuerva', María E. Iglesias² \\ 1. Universidad de Buenos Aires, Facultad de Odontología, Cátedra de Odontología Restauradora, Buenos Aires, Argentina \\ 2. Universidad de Buenos Aires, Facultad de Odontología, Cátedra de Materiales Dentales, Buenos Aires, Argentina
}

\begin{abstract}
The aim of this study was to analyze the dimensions of the clinical crown of upper central incisors and the prevalence of tooth shapes by two different protocols. Assessment was performed on each of the 111 dental stone type $V$ maxillae models of students of dentistry from Buenos Aires University [93 females and 18 males, mean age 23.70 ( \pm 2.26$)$ years] The mesial and distal-vestibular angles were defined on each right upper incisor, and the following segments were defined: $A B$ (zenith - incisal edge), CD, EF, GH (apical, middle, and incisal thirds - vestibule - mesial and vestibule-distal angles) and their lengths were determined with a precision caliper. Then, the $C D / A B, E F / A B$ and mean $C D-E F / A B$ ratios were calculated. Shapes were assessed by four independent observers, three of whom evaluated digital images of the models, while the fourth had no access to the images, and determined the shapes using an algorithm developed from the dimensions of the studied segments. Rates and confidence intervals were determined, and
\end{abstract}

Fleiss' Kappa was calculated to assess the agreement among the evaluators who worked with the images and among all of them.

Average incisor length was $10 \mathrm{~mm}$, and widths at $C D$ and EF were $7.35 \mathrm{~mm}(0.65)$ and $8.27 \mathrm{~mm}(0.58)$, respectively. Regarding shapes, $51.58 \%$ (47.90-55.20) of the incisors were identified as square, $18.02 \%(14.50-21.90)$ as ovoid and $30.41 \%$ (30.00-30.90) as triangular. Fleiss' Kappa agreement was 0.71 (0.62-0.80). The application of the proposed algorithm provided a considerable level of agreement among the observers. Regarding tooth size, both the average segment length and the proportions were similar to those reported by various authors.

Received: January 2021; Accepted: April 2021.

Keywords: incisors - dental esthetic - tooth, anatomy.

\section{Prevalencia de forma y tamaño de los incisivos centrales en estudiantes universitarios argentinos: determinación visual y mediante un nuevo método estandarizado}

\begin{abstract}
RESUMEN
El objetivo de este trabajo fue analizar las dimensiones de las coronas clínicas de incisivos centrales superiores, y la prevalencia de cada una de las formas dentarias según diferentes formas de determinación. Se utilizaron modelos de yeso tipo $V$ de 111 estudiantes (93 mujeres y 18 varones) con una media de edad de 23,70 (土2,26) años. Se definieron los ángulos vestíbulo - mesial y distal para los incisivos centrales superiores derechos (1.1), se definieron los siguientes segmentos: $A B$ (cenit - borde incisal), CD, EF, GH (tercios apical, medio e incisal - ángulos vestíbulo - mesial y vestíbulo- distal) $y$ se determinaron sus longitudes con un calibre de precisión. Se calcularon las proporciones $C D / A B, E F / A B$ y media $C D$ $E F / A B$. Las formas de las piezas dentarias fueron identificadas por cuatro observadores independientes, tres lo hicieron mediante la evaluación de imágenes digitales de los modelos confeccionados. El cuarto observador, sin acceso a las imágenes, asignó a cada pieza una de las formas determinadas
\end{abstract}

mediante la aplicación de un algoritmo elaborado ad-hoc. Se obtuvieron tasas e intervalos de confianza y se calculó Kappa de Fleiss para valorar la concordancia entre evaluadores.

La longitud promedio fue de $10 \mathrm{~mm}$ y el ancho en los segmentos CD y EF fueron de $7.35 \mathrm{~mm}$ (0.65) y $8.27 \mathrm{~mm}$ (0.58) respectivamente. En cuanto a formas el 51,58\% (47.90-55.20) de los incisivos estudiados fueron identificados como cuadrados, el $18.02 \%$ (14.50-21.90) como ovoides y el 30,41\% (30.00-30.90) triangulares. La concordancia de Kappa de Fleiss fue de 0.71 (0.62-0.80). La aplicación del algoritmo propuesto alcanzó un nivel de concordancia considerable entre los evaluadores. En cuanto al tamaño dentario, tanto la longitud promedio de los segmentos estudiados como las proporciones halladas son similares a las reportadas por diversos autores.

Palabras clave: incisivos - estética dental - anatomía dentaria. 


\section{INTRODUCTION}

The search for an attractive smile has become an increasingly frequent demand in dental practice. This has motivated material development and knowledge creation in the field of restorative dentistry ${ }^{1}$.

Over the years, dentists have planned cosmetic treatments based on a set of parameters, such as size, shape, color, alignment, and lines of symmetry of teeth ${ }^{2-5}$. As early as 1815, Schimmelpennick ${ }^{6}$ established the existence of five shapes for facial contours, upon which Williams relied in 1915 to define the three fundamentals of the vestibular faces of the upper central incisors as triangular, ovoid and square. Fradeani ${ }^{4}$ stated that triangular-shaped incisors are those in which the outer limits of the contour of the buccal aspect diverge towards the incisal, creating a narrow cervical area; ovoid incisors have external limits that tend to be curved and rounded and show a gradual reduction of the cervical area and the incisal edge, and square incisors have more or less straight, parallel external limits and therefore a wide cervical area and wide incisal edge.

Lombardi ${ }^{7}$ was one of the first authors to note the importance of tooth dimensions in relation to the sequence in which they are seen, from the central incisor to the first premolar, and established the upper central incisor as the dominant tooth by virtue of size and order of appearance in the smile. In terms of proportion, Davis ${ }^{8}$ noted that the generally accepted range for the width of the central incisor is $75-80 \%$ of its height.

Some authors have mentioned that tooth size and shape differ according to ethnicity, gender and dietary habits ${ }^{9}$, and others have even found apparent differences between individuals of the same ethnicity ${ }^{10-13}$. Sterrett et al. ${ }^{14}$, for example, analyzed the size of the antero-superior teeth with a caliper applied to dental gypsum models of Caucasians and found significant differences in the width and height of all the teeth studied. Chou et al. ${ }^{15}$ found that the vertical and horizontal dimensions of clinical crowns were significantly higher in men than in women. On the other hand, Tsukiyama et al. ${ }^{16}$ found that maxillary teeth appeared to be narrower in Asians than in Caucasian Swiss individuals.

Regarding evaluation of tooth dimensions, Olsson et al. ${ }^{17}$, in a study based on clinical photographs, established the length of the clinical crown as the distance between the gingival margin and the incisal edge, and after dividing this segment in three equal portions (cervical, middle and incisal), established the mesiodistal distance by assessing the height of the union of the cervical and middle portions as the width of the crown and, finally, they calculated the width/height ratio from the obtained data. All these parameters were applied by Chou et al. ${ }^{15}$ to determine the size of teeth on diagnostic stone models using a Mitutoyo caliper. Tsukiyama et al. ${ }^{16}$ and Olsson el al. ${ }^{17}$ used standardized highresolution images of ex-vivo teeth from white and Asian subjects on which they registered the widest section of the mesiodistal plane of the anatomical crown (perpendicular to the longitudinal axis of the tooth) and the greatest cervico-incisal distance of the anatomical crown (parallel to the longitudinal axis of the tooth). In the same way, Sandeep et al. ${ }^{18}$ used both resources (dental stone models and digital photographs) from a South Indian population, and using a digital caliper, defined crown width as the widest distance between the mesial and distal contact points (perpendicular to the axis longitudinal of the tooth), and crown length as the longest distance between the cervical margin and the incisal edge (parallel to the longitudinal axis of the tooth). The literature contains studies by different authors evaluating tooth shape, some of which have used the Kappa concordance test, which provided values that could be considered as moderate concordance according to the studies by Landis and Koch ${ }^{19-21}$.

To date, no publication has been found regarding the size and shape of the maxillary anterior tooth segment in the population of Argentina.

The aim of this study was to analyze the dimensions of the clinical crown of upper central incisors and the prevalence of each tooth shape described according to different methods of determination, in models from fourth-year dentistry students from Buenos Aires University, Argentina.

\section{MATERIALS AND METHODS}

This study was conducted on models of the upper jaw of 111 students [ 93 female and 18 male, mean age 23.70 (SD 2.26) years], at Buenos Aires University. Exclusion criteria were presence of total or partial peripheral restorations, fractures or carious and non-carious lesions in upper central incisors, and absence of any of the central incisors.

Models made of dental stone type V (Prima Rock; WhipMix Corp., Louisville, KY, USA) were used. 
Frontal images were taken of each model and sent to three observers $(\mathrm{O} 1, \mathrm{O} 2$ and $\mathrm{O} 3)$, who assigned one of the following shapes to each incisor: square $(\mathrm{S})$, ovoid $(\mathrm{O})$ or triangular $(\mathrm{T})$, in an Excel (Microsoft) spreadsheet. After the photographic record, the following were identified in each model: the vestibule-mesial and vestibule-distal angles (with a homogeneous line (L) obtained by sliding an automatic pencil tangent to the respective proximal faces. Fig. 1 shows the zenith (A) and the midpoint of the incisal edge (B) of the right central incisor. Once segment A-B had been traced on each tooth, its length $(\mathrm{AB})$ was determined and divided into three equal parts; cervical (C), middle (M) and incisal (I), with two segments whose external limits were defined by their intersection with L. In this way, CD (middle limit of the cervical third) and EF (incisal limit of the middle third) were established, as shown in Fig. 2.

A precision gauge (Compas Castroviejo; Ref. 3337.04, Prodont Holliger, La Marnasse, Olliergues, France) was used to determine the lengths of segments $\mathrm{AB}, \mathrm{CD}, \mathrm{EF}$ and $\mathrm{GH}$ for each upper right central incisor (1.1) in each mode ${ }^{15}$. Then the ratios $\mathrm{CD} / \mathrm{AB}, \mathrm{EF} / \mathrm{AB}$ and mean $\mathrm{CD}-\mathrm{EF} / \mathrm{AB}$ were calculated. The information was sent to a fourth observer (O4), who had no access to the images of the models and was asked to assess the shape of each

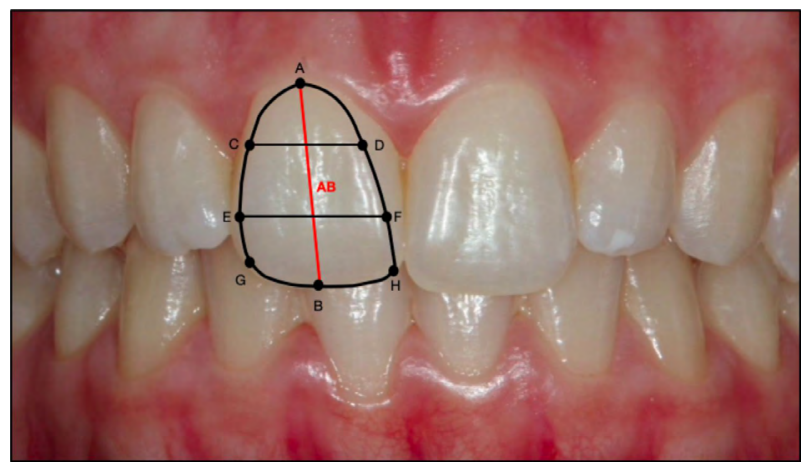

Fig. 1: The image shows segment $A B$, formed by points $A$ and $B$, which determines the upper crown. Segments $C D, E F$ and $G H$ define the dimensions of the cervical, middle and incisal thirds.

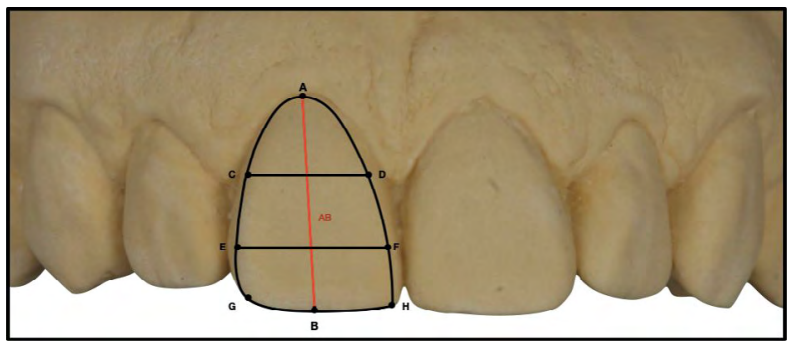

Fig. 2: Gypsum model with delimited segments. incisor according to the algorithm shown in Fig. 3, for which basic criteria are summarized in Table 1.

The dimensions of segments and proportions of the incisors were statistically analyzed with descriptive statistics: mean, median, mode, minimum and maximum values and range. The prevalence rates (CI 95\%) of each shape were calculated according to each form of determination. Agreement among observers 1, 2 and 3, and among observers 1, 2, 3 and 4 was assessed using Fleiss' Kappa. Comparison between sexes was made using 1-way ANOVA with a significance level of 0.05 .

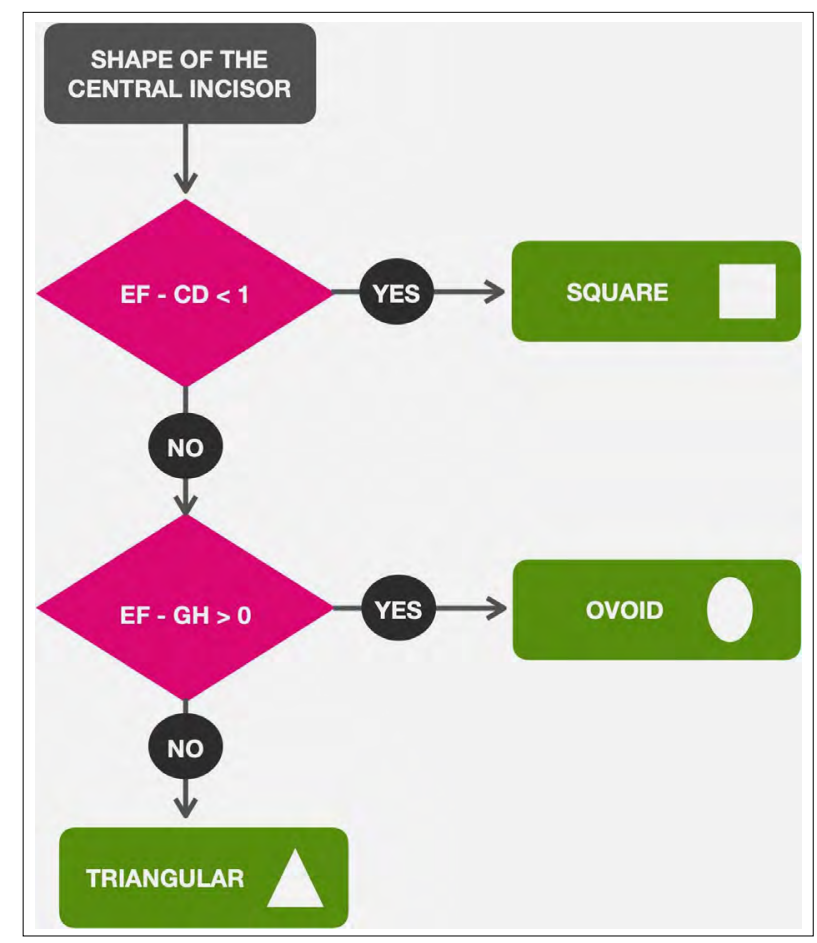

Fig. 3: Algorithm to standardize the assessment of tooth shape.

Table 1. Criteria for assigning tooth shape

Square EF-CD $<1$

Ovoid EF-CD $\geq 1$ and EF-GH $>0$

Triangular $E F-C D \geq 1$ and $E F-G H \leq 0$

\section{RESULTS}

The mean (SD) of segment $\mathrm{AB}$ (length) of the incisors studied was $10(0.97) \mathrm{mm}$ with a range of $5.80 \mathrm{~mm}$, while the means (SD) of the three width segments $\mathrm{CD}$, EF and GH were $7.35(0.65) \mathrm{mm}$, $8.27(0.58) \mathrm{mm}$, and $8.20(0.55) \mathrm{mm}$, respectively (Table 2).

Mean proportions (SD) were $0.74(0.08)$ for $\mathrm{CD} /$ $\mathrm{AB}, 0.83(0.08)$ for $\mathrm{EF} / \mathrm{AB}$, and $0.79(0.08)$ for $\mathrm{CD}$ $\mathrm{EF} / \mathrm{AB}$ (Table 3). 
Table 2. Descriptive statistics of lengths of segments $A B, C D$, EF and GH

\begin{tabular}{|l|c|c|c|c|c|c|}
\hline & Mean (SD) & Median & Mode & Minimum & Maximum & Range \\
\hline AB & $10.00(0.97)$ & 10.00 & 10.40 & 7.40 & 13.20 & 5.80 \\
\hline CD & $7.35(0.65)$ & 7.30 & 7.00 & 6.00 & 9.10 & 3.10 \\
\hline EF & $8.27(0.58)$ & 8.20 & 8.20 & 6.90 & 9.60 & 2.70 \\
\hline GH & $8.20(0.55)$ & 8.20 & 8.00 & 6.50 & 9.80 & 3.30 \\
\hline
\end{tabular}

Table 3. Descriptive statistics of the proportions between AB and CD, EF and the mean CD-EF

\begin{tabular}{|c|c|c|c|c|c|}
\hline & Mean $(\mathbf{d s})$ & Median & Mode & Minimum & Maximum \\
\hline CD/AB & $0.74(0.08)$ & 0.74 & 0.85 & 0.55 & 0.98 \\
\hline EF/AB & $0.83(0.08)$ & 0.84 & 0.84 & 0.66 & 1.08 \\
\hline CDEF/AB & $0.79(0.08)$ & 0.79 & 0.79 & 0.61 & 1.03 \\
\hline
\end{tabular}

Regarding the prevalence (CI 95\%) of the different shapes, on average, $51.58 \%(47.90-55.20)$ of the incisors studied were identified as square, $18.02 \%$ (14.50 - 21.90) as ovoid, and 30.41\% (30.00 - 30.90) as triangular (Fig. 4). In terms of the agreement among the different observers and the different assessment modes, the three observers who assessed incisor shape through photographs reached an agreement of $80.48 \%$ with a Fleiss' kappa of 0.71 (0.62-0.80). When the fourth observer, who assigned the shape by applying the proposed algorithm, was included in the analyses, the overall agreement was $71.77 \%$, Fleiss' kappa: 0.58 (0.50-0.66) (Table 4). In terms of effect of sex on the dimensions of incisor 1.1, after data analysis, statistical difference $(\mathrm{P}<0.05)$ was found only in segment $\mathrm{AB}$ (Table 5).

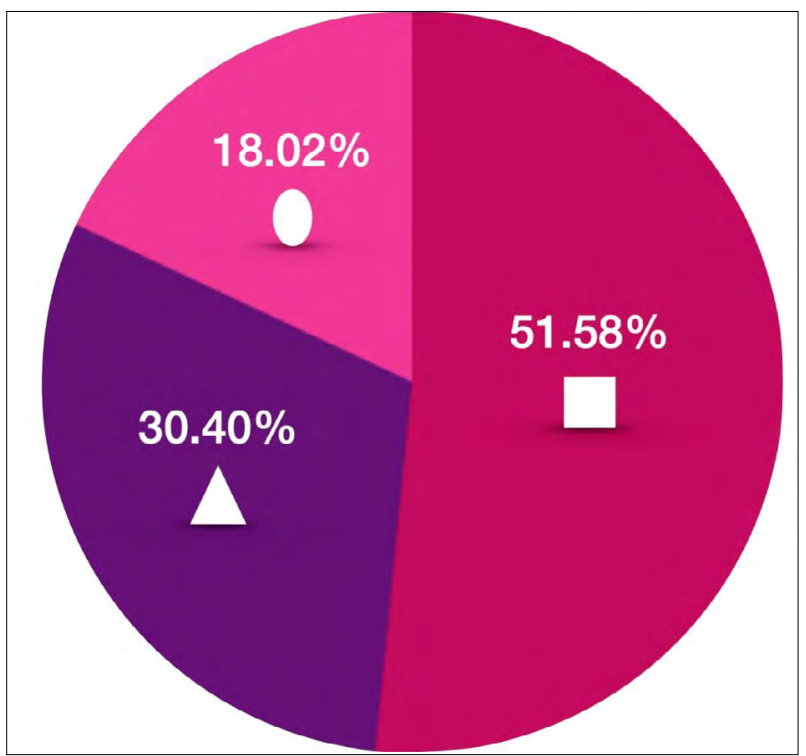

Fig. 4: Prevalence of different tooth shapes

Table 4. Prevalence of shapes assigned by the different observers and agreement rate between them (CI 95\%)

\begin{tabular}{|c|c|c|c|c|}
\hline & Observer 1 & Observer 2 & Observer 3 & Observer 4 \\
\hline Square & $\begin{array}{c}46.85 \\
(37.31-56.55)\end{array}$ & $\begin{array}{c}50.45 \\
(40.80-60.80)\end{array}$ & $\begin{array}{c}54.95 \\
(45.22-64.41)\end{array}$ & $\begin{array}{c}54.05 \\
(44.33-63.55)\end{array}$ \\
\hline Ovoid & $\begin{array}{c}22.52 \\
(15.14-31.43)\end{array}$ & $\begin{array}{c}19.82 \\
(12.86-28.46)\end{array}$ & $\begin{array}{c}14.41 \\
(8.47-22.35)\end{array}$ & $\begin{array}{c}15.32 \\
(9.18-23.39)\end{array}$ \\
\hline Triangular & $\begin{array}{c}30.63 \\
(22.26-40.09)\end{array}$ & $\begin{array}{c}29.73 \\
(21.43-39.15)\end{array}$ & $\begin{array}{c}30.63 \\
(22.23-40.09)\end{array}$ & $\begin{array}{c}30.63 \\
(22.23-40.09)\end{array}$ \\
\hline \multirow{2}{*}{$\begin{array}{l}\text { eiss' kappa (free } \\
\text { arginal (Cl95\%) }\end{array}$} & \multicolumn{3}{|c|}{ Overall agreement: $80.48 \%$ Fleiss' kappa: $0.71(0.62-0.80)$} & \\
\hline & \multicolumn{4}{|c|}{ Overall agreement: $71.77 \%$ Fleiss' kappa: 0.58 (0.50-0.66) } \\
\hline
\end{tabular}

Table 5. Mean (SD) of dimensions and proportions according to sex

\begin{tabular}{|c|c|c|c|c|c|}
\hline Sex & AB & CD & EF & CD/AB & EF/AB \\
\hline $\begin{array}{c}\text { Female } \\
(n=93) 84 \%\end{array}$ & $9.90(0.93)$ & $7.33(0.65)$ & $8.24(0.56)$ & $0.75(0.08)$ & $0.84(0.08)$ \\
\hline $\begin{array}{c}\text { Male } \\
(n=18) 16 \%\end{array}$ & $10.52(1.01)$ & $7.47(0.62)$ & $8.41(0.64)$ & $0.71(0.05)$ & $0.80(0.06)$ \\
\hline $\mathbf{P}$ & 0.01 & 0.40 & 0.25 & 0.11 & 0.08 \\
\hline
\end{tabular}




\section{DISCUSSION}

One of the greatest difficulties in the oral rehabilitation process is the successful restoration of aesthetics and function, for which the correct determination of the dimension and shape of the teeth is a key factor. Therefore, the finding of certain anatomical references in terms of tooth size and shape in order to standardize their assessment, could be relevant ${ }^{19}$.

Although various authors have studied the morphology and tooth size of the upper central incisor in different ethnic groups over the years, no publication referring to inhabitants of Argentina has been found.

According to tooth size, the values obtained in the current study for segment $\mathrm{AB}$ (crown length) are similar to the results reported by authors who studied populations from Asia (Taiwan), in which $52 \%$ males and $48 \%$ females were evaluated ${ }^{15}$. This similarity could be due to the proportion of females in the cohort of in the present study $(84 \%$ females and 16\% males). Different results were obtained by other authors who compared an Asian population (Japan) to a Caucasian population (Switzerland), without specifying sex, on ex-vivo teeth, for which the reference points used for the determination of crown length were not the same ${ }^{16}$. Various reference points have been used for the determination of the crown length and mean width in different publications. Several authors found similar results in Asian populations, but they differ from the Caucasian populations studied in their publications ${ }^{15,16}$. This discrepancy could be due to the higher percentage of females in the current study. Regarding the width/height ratio of the clinical crown of the upper central incisor, our study found similar results to those reported for Asian (Japan, Taiwan), Caucasian (Switzerland, Sweden) and southern Indian populations, so it would seem that although the absolute dimensions vary among ethnic groups, the proportions appear to differ to a lesser extent ${ }^{15-18}$.

On the other hand, the results of the crown width/ height ratio found in the current study are within the $75-80 \%$ percentage described by Davis as aesthetically pleasing values. ${ }^{8}$

Several studies report that the mean width and height of the clinical crowns of front upper teeth were significantly greater in males than in females of the study populations ${ }^{11-15}$. In the current study, the only dimension that was found to be significantly greater in males than in females was crown length (AB). This may be due to the low proportion of males in the study population, so future research should consider a population with higher proportion of males.

Regarding the prevalence of upper central incisor shapes, all the observers reported highest frequency for square shape $(51.58 \%)(47.90$ - 55.20) followed by triangular (30.41\%) (30.00 - 30.90), and lastly, ovoid (18.02\%) (14.50 - 21.90). Paranhos et al. obtained different results, with a higher prevalence of ovoid teeth, followed by quadrangular and triangular teeth, in a study on a Caucasian population in $\mathrm{Brazil}^{20}$.

The concordance among the different observers who assigned the tooth shapes was evaluated using Fleiss' Kappa test. Paranhos et al. and Furtado et al. found $\mathrm{k}$ values of 0.52 and 0.42 , respectively ${ }^{19,20}$. In the present study, values of $0.58(0.50-0.66)$ were found among the four observers, three of whom had access to images of the incisors, while the fourth assigned the shapes only by applying the proposed algorithm, without access to images of the models. This level of agreement is considerable, based on the studies by Landis and $\mathrm{Koch}^{21}$, so we can say that the application of the proposed algorithm to standardize the assessment of tooth shape enabled agreement values among evaluators that were similar to or higher than those obtained in studies in which all observers had visual access to models or images of the teeth studied.

\section{CONCLUSION}

Evaluation of shapes by means of the proposed algorithm agreed with evaluation of shapes by means of direct observation.

Within the limitations of the present study, it can be concluded that the most prevalent shape in the study population is square, followed by triangular and then ovoid.

Regarding tooth size, both the average length of the segments studied, and the proportions found are similar to those reported by various authors. 


\section{DECLARATION OF CONFLICTING INTERESTS}

The authors declared no potential conflicts of interest with respect to the research, authorship, and/or publication of this article.

\section{FUNDING}

None

\section{REFERENCES}

1. Gurel G, Sesma N, Calamita MA, Coachman C, Morimoto $\mathrm{S}$. Influence of Enamel Preservation on Failure Rates of Porcelain Laminate Veneers. Int J Periodontics Restorative Dent 2013;33:31-39.

2. Belser UC. Esthetics checklist for the fixed prosthesis. Part II: Biscuit-bake try-in. In: Scharer P, Rinn LA, Kopp FR, editors. Esthetic guidelines for restorative dentistry. Chicago: Quintessence; 1982. p. 188-192.

3. Magne $P$, Belser U, Natural oral esthetics. In: Magne $\mathrm{P}$, Belser $\mathrm{U}$, editors. Bonded porcelain restorations in the anterior dentition: a biomimetic approach. Chicago: Quintessence; 2002. p. 57-96.

4. Fradeani M.; Rehabilitación Estética en Prostodoncia Fija. Vol.1; Ed. Quintessence. 1ed.,2006.

5. Kina S., Bruguera A; Invisible. Restauraciones Estéticas Cerámicas. Vol.1; Ed. Panamericana, 2008.

6. Aprile H, Figum ME, Garino R. Anatomía Odontológica funcional y aplicada. Ed El Ateneo.5 ed.,1971.

7. Lombardi RE. The principles of visual perception and their clinical application to denture esthetics. J Prosthet Dent $1973 ; 23: 358-382$.

8. Davis NC. Smile design. Dent Clin North Am 2007;51:299318 .

9. Olsson M, Lindhe J. Periodontal characteristics in individuals with varying form of the upper central incisors. J Clin Periodontol 1991; 18:78-82.

10. Townsend GC, Brown T. Heritability of permanent tooth size. Am J Phys Anthropol 1978 49:497- 504.

11. Lavelle CL. Maxillary and mandibular tooth size in different racial groups and in different occlusal categories. Am J Orthod 1972; 61: 29-37.

12. Doris JM, Bernard BW, Kuftinec MM, Stom D. A biometric study of tooth size and dental crowding. Am J Orthod 1981; 79: 326-336.

\section{CORRESPONDENCE}

Dr. Maria M. Trigo-Humaran

Cátedra de Odontología Restauradora,

Facultad de Odontología, UBA

Marcelo T. de Alvear 2142 9A, C1122AAH,

Ciudad Autónoma de Buenos Aires, Argentina

milagros.trigo@odontologia.uba.ar

13. Gillen RJ, Schwartz RS, Hilton TJ, Evans DB. An analysis of selected normative tooth proportions. Int J Prosthodont 1994; 7: 410- 417.

14. Sterrett JD, Oliver T, Robinson F, Fortson W, Knaak B, Russell CM. Width/length ratios of normal clinical crowns of the maxillary anterior dentition in man. J Clin Periodontol 1999; 26: 153-157.

15. Chou Yu- Hsiang, Chi-cheng TsaiJen-Chyan Wang, Ya-Ping Ho, Kun-Yen Ho, Chuen-Chyi Tseng. New classification of crown forms and gingiva characteristics in Taiwanese. Open Dent J 2008; 2:114-119.

16. Tsukiyama T, Marcushamer E, Griffin TJ, Arguello E, Magne P, Gallucci GO, Comparison of the anatomic crown width/length ratios of unworn and worn maxillary teeth in Asian and white subjects. J Prosthet Dent 2012;107:11-16.

17. Olsson M, Lindhe J, Marinello CP: On the relationship between crown form and clinical features of the gingiva in adolescents. J Clin Periodontol 1993; 20: 570-577.

18. Sandeep N, Satwalekar P, Srinivas S, Reddy CS, Reddy GR, Reddy BA. An analysis of maxillary anterior teeth dimensions for the existence of golden proportion: clinical study. JInt oral health 2015; 7:18-21.

19. Furtado GC, Furtado A, El Haje OA, Butignon LE, Pesqueira AA, Paranhos LR. Relationship between the morphology of the maxillary central incisor and horizontal and vertical measurements of the face. Indian J Dent Res. 2020 25: 178-183.

20. Paranhos LR, Souto Lima C, Alves da Silva RH, Daruge Júnior E, Torres FC. Correlation between maxillary central incisor crown corphology and candibular dentala form in normal occlusion subjects. Braz Dent J 2012; 23: 149-153.

21. Landis JR, Koch GG. The measurement of observer agreement for categorical data. Biometrics 33, 159-174. 